\title{
NPR2 is involved in FSH-mediated mouse oocyte meiotic resumption
}

\author{
Lei Yang ${ }^{1,2+}$, Qiang Wei ${ }^{1,2+}$, Wei Li ${ }^{1,2}$, Qihui Xi ${ }^{1,2}$, Xiaoe Zhao ${ }^{1,2}$ and Baohua Ma ${ }^{1,2^{*}}$
}

\begin{abstract}
Background: Previous studies have reported that follicle-stimulating hormone (FSH) is often added to culture media to induce oocyte meiotic resumption and maturation and to improve subsequent embryonic development during in vitro maturation (IVM). However, the underlying mechanisms remain unclear.

Methods: Cumulus-oocyte complexes (COCs) were collected from ovaries 46-48 h after the female mice were intraperitoneally injected with $8 \mathrm{IU}$ equine chorionic gonadotropin (eCG) and then the COCs were cultured in different medium. qRT-PCR analysis was used to assess mRNA expression of EGF-like factors and natriuretic peptide receptor 2 (NPR2). Western Blot analysis was used to assess phosphorylation of mitogen-activated protein kinase 3/1 (MAPK3/1). The oocytes were morphologically assessed for meiotic resumption.

Results: FSH stimulated the expression of EGF-like factors, the activation of MAPK3/1, a decrease in NPR2 mRNA and oocyte meiotic resumption. Moreover, the FSH-induced decrease in NPR2 and oocyte meiotic resumption occurred via the MAPK3/1 singling pathway, which was activated by the epidermal growth factor receptor (EGFR) pathway.

Conclusions: NPR2 is involved in FSH-mediated oocyte meiotic resumption, and this process is associated with the EGFR and MAPK3/1 signaling pathways.

Keywords: Meiotic resumption, Follicle-stimulating hormone, Epidermal growth factor receptor, Mitogen-activated protein kinase 3/1, Natriuretic peptide receptor 2
\end{abstract}

\section{Background}

During oocyte maturation, oocytes acquire the competence to progress through meiosis because they have assembled the necessary cell cycle machinery [1]. However, oocytes remain in this suspended state because signals from the granulosa cell compartment preclude the activation of this machinery that is required for entry into metaphase. The nature of these signals is now better understood; C-type natriuretic peptide (CNP) and its cognate receptor, the natriuretic peptide receptor 2 (NPR2) have been shown to promote cyclic guanosine monophosphate (cGMP) production in granulosa and cumulus cells [2]. cGMP diffuses into oocytes through gap junctions and inhibits the activity of phosphodiesterase 3A (PDE3A), resulting in the prevention of cyclic adenosine monophosphate (cAMP) degradation

\footnotetext{
* Correspondence: baohuama@163.com

${ }^{\dagger}$ Equal contributors

${ }^{1}$ Key Laboratory of Animal Biotechnology of the Ministry of Agriculture, Northwest A\&F University, Yangling, Shaanxi 712100, China

${ }^{2}$ College of Veterinary Medicine, Northwest A\&F University, Yangling, Shaanxi 712100, People's Republic of China
}

[3]. Elevated cAMP promotes the phosphorylation of cyclindependent kinase 1 (CDK1) and inactivates maturationpromoting factor (MPF) $[4,5]$ to maintain oocyte meiotic arrest.

When immature oocytes are isolated from follicles and cultured in vitro, the oocytes spontaneously resume meiosis because of their removal from the inhibitive environment of follicles [6, 7]. However, the subsequent developmental competence of oocytes matured in vitro is compromised compared with that of oocytes matured in vivo [8-10]. Gonadotrophin orchestrates the acquisition of oocyte competence, both in vivo and in vitro; therefore, in vitro culture systems of media were often supplemented with gonadotrophins, such as follicle-stimulating hormone (FSH), to incumulus cell expansion, nuclear maturation and mic maturation and to improve embryonic devel[14], cow [15], horse [16] and dog [17]. The molecular mechanisms by which gonadotrophins induce oocyte meiotic resumption is partly mediated by increasing the 
production of cAMP $[18,19]$ and subsequently activating mitogen-activated protein kinase 3/1 (MAPK3/1) in its surrounding cumulus granulosa cells [20-22]. Recent findings indicate that FSH induces the expression of epidermal growth factor (EGF)-like factors [23, 24] and activates the epidermal growth factor receptor (EGFR), which further activates MAPK3/1 [25]. In addition, recent studies reported that FSH decreased NPR2 expression in pig cumulusoocyte complexes (COCs) [26] and the EGFR signaling pathway inhibited NPR2 expression via the MAPK3/1 signaling pathway in mouse COCs [27].

As mentioned above, EGFR, MAPK3/1 and NPR2 have been shown to participate in oocyte meiotic resumption; however, direct evidence indicating their relationships with FSH have not yet been reported. The present study aimed to determine the molecular mechanisms of FSH on oocyte meiotic resumption, especially the possible correlations among FSH, EGFR, MAPK3/1 and NPR2, and to elucidate the signal transduction pathways involved in this process.

\section{Methods}

\section{Chemicals and mice}

All chemicals were purchased from Sigma-Aldrich (St. Louis, MO, USA) unless otherwise stated. CNP, FSH and EGF were prepared as stock solutions in distilled PBS containing $0.1 \%$ BSA. Stock solutions of the EGFR inhibitor AG1478 and the MAPK3/1 inhibitor U0126 (10 $\mathrm{mM}$ and $5 \mathrm{mM}$, respectively) were prepared in DMSO and stored at $-20{ }^{\circ} \mathrm{C}$. The final concentrations of EGF, AG1478 and U0126 for culture COCs were $100 \mathrm{ng} / \mathrm{ml}, 10 \mu \mathrm{M}$ and $5 \mu \mathrm{M}$, respectively. Prior to use, they were diluted with culture medium, and the final concentration of DMSO was $0.1 \%$. Immature 21 - to 35 -day-old female mice (Kunming White outbred strain) were obtained from the Laboratory Animal Center of The Fourth Military Medical University. The mice were housed in an environment with controlled temperature and humidity, a 12 h light dark cycle, and ad libitum access to food and water. The present study was reviewed and approved by the Institutional Animal Care and Use Committee of College of Veterinary Medicine, Northwest A\&F University.

\section{Oocyte collection, oocyte culture and oocyte assessment}

In vitro oocyte maturation was performed as previously described with slight modifications [28]. COCs were collected from ovaries $46-48 \mathrm{~h}$ after the female mice were intraperitoneally injected with 8 IU equine chorionic gonadotropin (eCG). COCs were released from antral follicles by puncturing the follicles with a needle in culture medium. The culture medium used for this study was $\alpha$-minimal essential

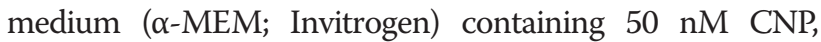

$0.23 \mathrm{mM}$ sodium pyruvate, $2 \mathrm{mM}$ glutamine, $3 \mathrm{mg} / \mathrm{ml}$ BSA, $75 \mathrm{IU} / \mathrm{ml}$ potassium penicillin $\mathrm{G}$ and $50 \mathrm{mg} / \mathrm{ml}$ streptomycin sulfate. LH, EGF, AG1478 and U0126 were added either alone or in combination at the start of culture. In each experiment, a group of 30 COCs were cultured in a $60 \mu \mathrm{l}$ drop covered with paraffin oil in a $3.5-\mathrm{mm}$ culture dish. All cultures were incubated at $37{ }^{\circ} \mathrm{C}$ in a humidified atmosphere of $5 \% \mathrm{CO}_{2}$ in air [29]. COCs were denuded mechanically by repeated pipetting to remove cumulus cells at the end of culture. The oocytes were then morphologically assessed for meiotic resumption.

\section{RNA isolation and qRT-PCR}

The COCs of each treatment were pooled for RNA extraction. Total RNA was extracted using Trizol reagent (Invitrogen/Life Technologies, Carlsbad, CA). Firststrand cDNA was synthesized according to the manufacturer's instructions (PrimeScript ${ }^{\circ}$ RT reagent Kit). qRT-PCR was performed using an ABI StepOnePlus

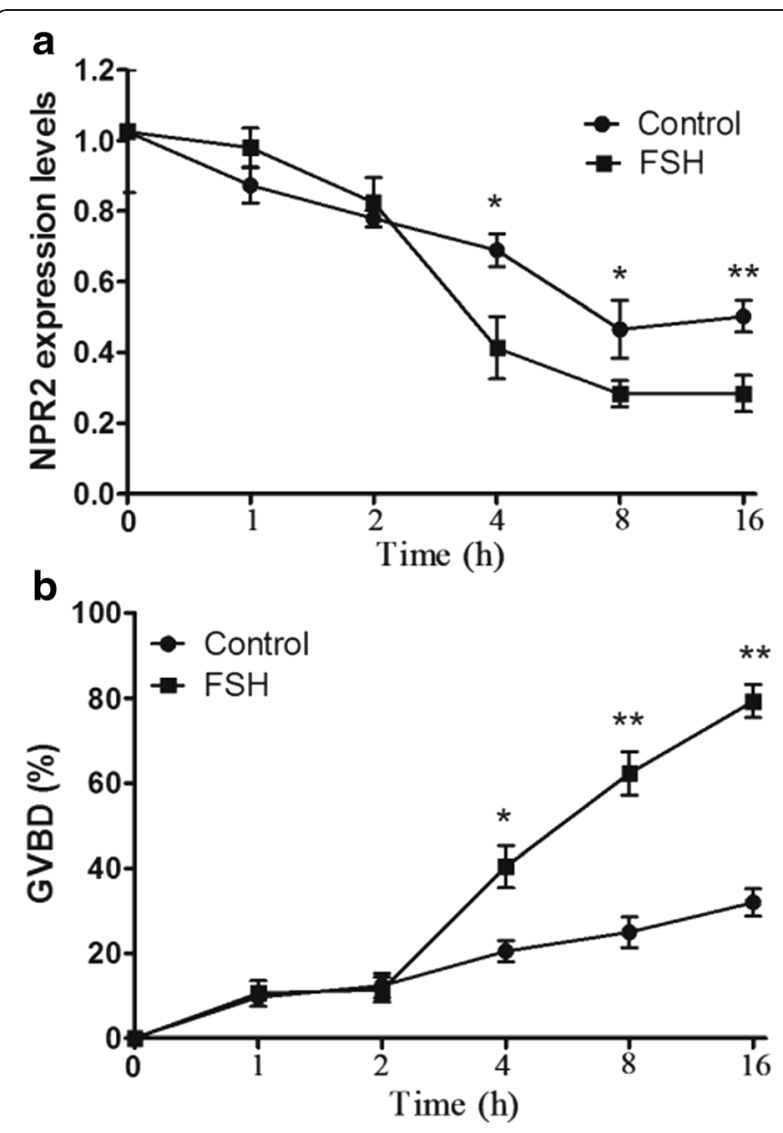

Fig. 1 The effects of FSH on oocyte meiotic resumption and NPR2 mRNA expression in COCs. a Kinetics of oocyte meiotic resumption after FSH induction in COCs at different times. $\mathbf{b}$ Patterns of NPR2 mRNA expression after FSH induction in COCs at different times. The results are presented as the mean \pm SEM and are representative of three independent experiments. ${ }^{*} P<0.05$ and ${ }^{* *} P<0.01$ compared with each corresponding group in the control 
Real-time Detection System (AB, CA, and USA) and SYBR Green qPCR SuperMix (Invitrogen, USA). Each experiment was repeated independently at least three times, and the fold change in the expression of each gene was analyzed using the $2-{ }^{\Delta \Delta C T}$ method. All of the primers were used as previously reported [2, 30], and the L19 ribosomal protein gene (RPL19) was used as the internal control.

\section{Western blot analysis}

To detect phosphorylated MAPK3/1, approximately 120 COCs for each treatment were lysed using $120 \mu \mathrm{l} 1 \times$ SDS supplemented with $1 \mathrm{mM}$ phenylmethylsulfonyl fluoride and $1 \mathrm{mM}$ sodium orthovanadate for $20 \mathrm{~min}$ on ice, and then the samples were stored at $-20{ }^{\circ} \mathrm{C}$. Before electrophoresis, the samples were heated to $100{ }^{\circ} \mathrm{C}$ for 5 min, cooled on ice immediately, and then centrifuged at $12,000 \mathrm{~g}$ for $5 \mathrm{~min}$. Each sample was separated by $12 \%$ SDS-PAGE and electro-transferred onto a PVDF membrane. After incubation in blocking buffer for $1 \mathrm{~h}$ at $37{ }^{\circ} \mathrm{C}$, the membrane was incubated overnight at $4{ }^{\circ} \mathrm{C}$ with anti-MAPK3/1, anti-pMAPK3/1 (Cell Signaling Technology; 1:1000 dilutions) or $\beta$-actin (1:1000; Beijing CWBIO Co., Ltd., Beijing, China) as a loading control. After washing, the membranes were incubated with secondary antibody conjugated to horseradish peroxidase at $37{ }^{\circ} \mathrm{C}$ for $30 \mathrm{~min}$. Finally, immunoreactive bands were visualized using a Super Signal West Pico kit according to the manufacturer's instructions.

\section{Statistical analyses}

All experiments were repeated at least three times for each group, and the data are presented as the mean \pm SEM. The data were analyzed by ANOVA, followed by Fisher's least significant difference test and independent samples Student's $t$ test, with SPSS software, version 13.0 (SPSS, Chicago, IL, USA).

\section{Results}

FSH decreases NPR2 mRNA expression and promotes oocyte meiotic resumption

To test the possibility that NPR2 signaling mediates FSH-induced oocyte meiotic resumption, we first examined the effects of FSH on oocyte meiotic resumption and NPR2 expression during oocyte maturation in vitro. The COCs were cultured with $2 \mathrm{IU} / \mathrm{ml} \mathrm{FSH}$ for different lengths of time $(0,1,2,4,8$ and $16 \mathrm{~h})$. The pattern of NPR2 mRNA expression levels during the culture in vitro was similar to the oocyte meiotic resumption rate (Fig. 1). We found that the expression of NPR2 in the
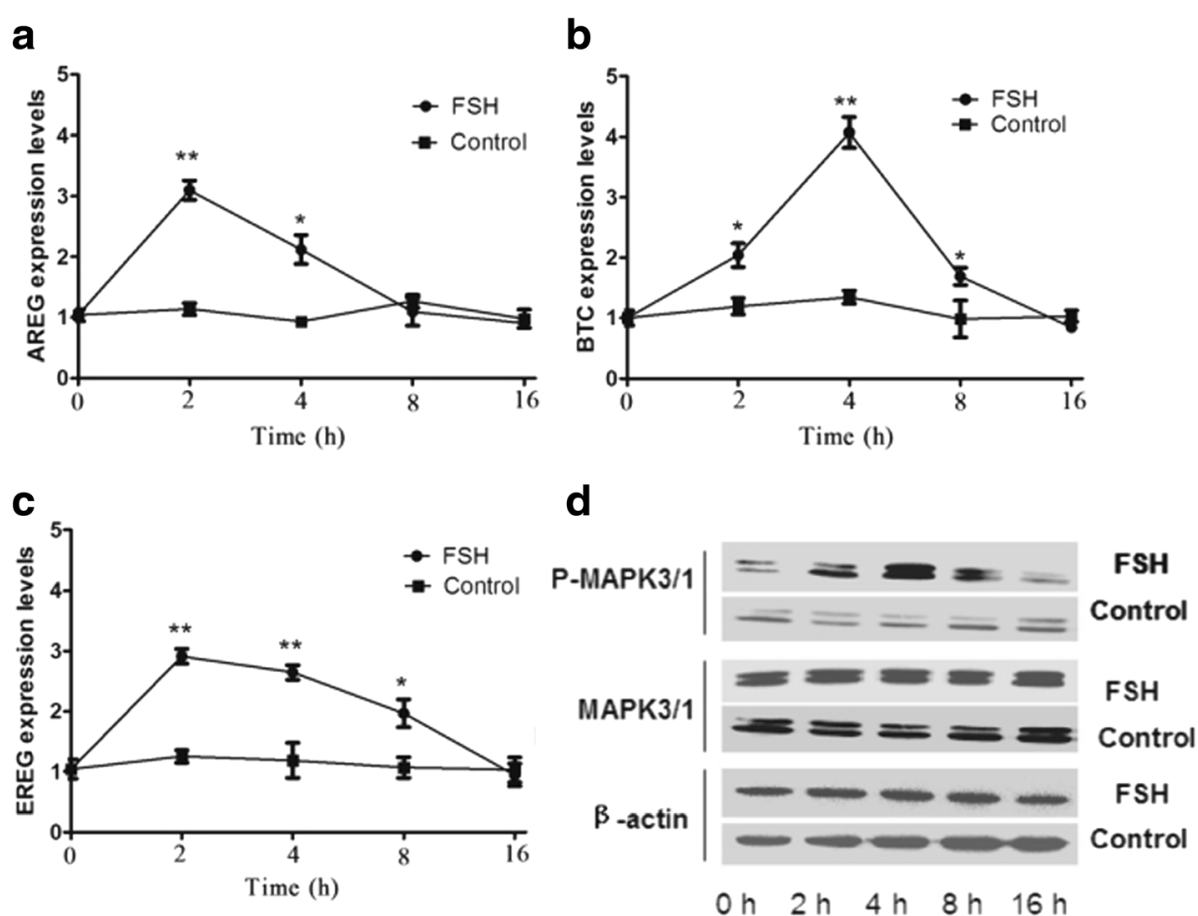

Fig. 2 The effects of FSH on the mRNA expression of EGF-like factors and the activation of MAPK3/1 in COCs. a The mRNA expression of AREG after stimulation with or without FSH at different times. $\mathbf{b}$ The mRNA expression of BTC after stimulation with or without FSH at different times. $\mathbf{c}$ The mRNA expression of EREG after stimulation with or without FSH at different times. $\mathbf{d}$ The activation of MAPK3/1 after stimulation with or without FSH at different times. The results are presented as the mean \pm SEM and are representative of three independent experiments. ${ }^{*} P<0.05$ and ${ }^{* *} P<0.01$ compared with each corresponding group in the control 
FSH-stimulated COCs significantly decreased after $4 \mathrm{~h}$ of culture and remained at low levels until the end of the experiment at $16 \mathrm{~h}$ (Fig. 1a). The kinetics of germinal vesicle breakdown (GVBD) showed that, compared with control groups without FSH treatment, a significant increase in GVBD occurred $4 \mathrm{~h}$ after FSH stimulation (Fig. 1b) when the NPR2 mRNA expression levels were decreased to approximately $55 \%$ of the baseline levels.

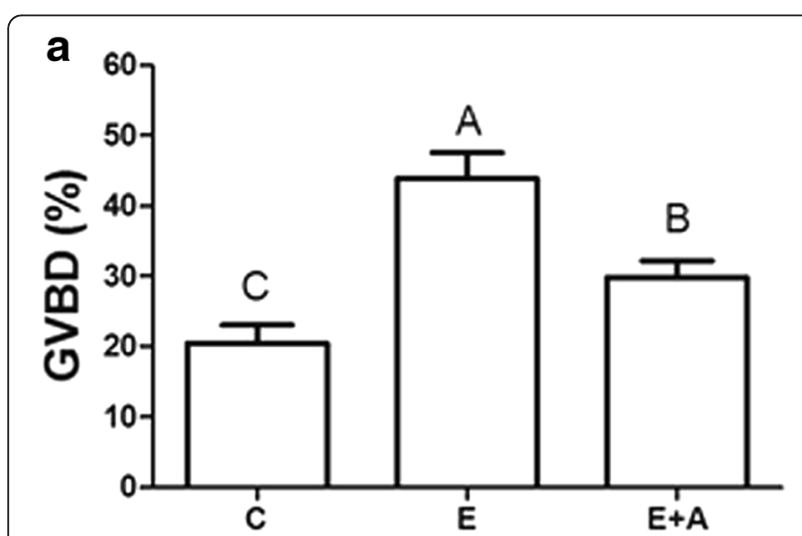

b

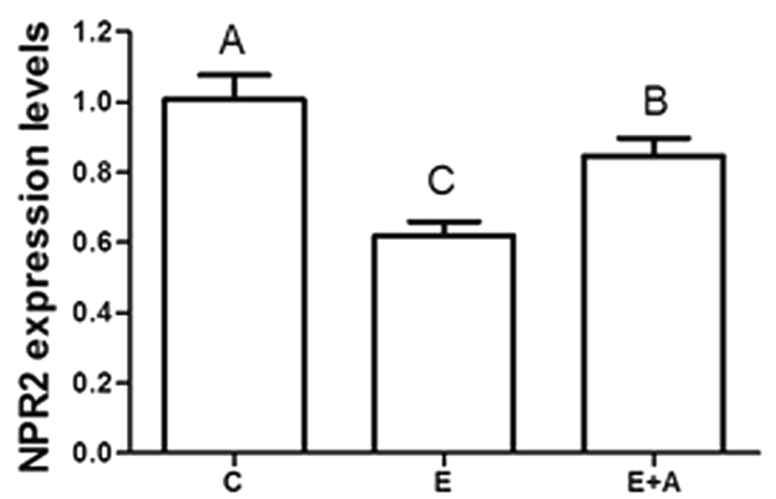

C

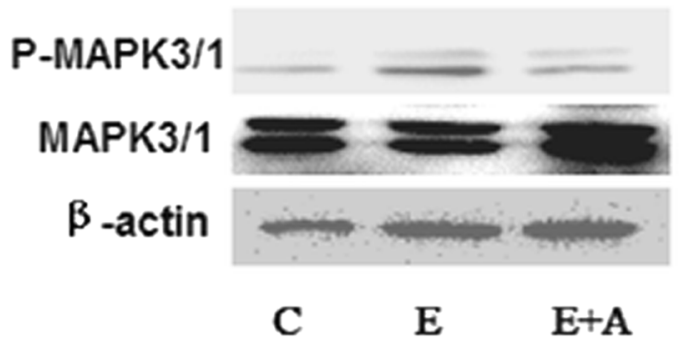

Fig. 3 The effects of EGF on oocyte meiotic resumption, NPR2 mRNA expression and MAPK3/1 activation in COCs at $4 \mathrm{~h}$. a The GVBD rates after stimulation with EGF or EGF plus AG1478 in COCs. b The mRNA expression of NPR2 after stimulation with EGF or EGF plus AG1478 in COCs. c The phosphorylation of MAPK3/1 after stimulation with EGF or EGF plus AG1478 in COCs. The results are presented as the mean \pm SEM and are representative of three independent experiments. C: Control; E: EGF; A: AG1478. Different letters represent significant differences $(P<0.05)$
FSH stimulates mRNA expression of EGF-like factors and phosphorylation of MAPK3/1

Previous reports showed that the release of EGF-like factors $[31,32]$ and the activation of MAPK3/1 [33] are necessary for $\mathrm{FSH}$-induced oocyte meiotic resumption. We examined the effect of FSH on the expression of EGF-like factors mRNA and MAPK3/1 activity after $0 \mathrm{~h}, 2 \mathrm{~h}, 4 \mathrm{~h}, 8 \mathrm{~h}$ and $16 \mathrm{~h}$ of culture, respectively. FSH significantly stimulates the mRNA expression of EGF-like factors, including amphiregulin (AREG), betacellulin (BTC) and epiregulin

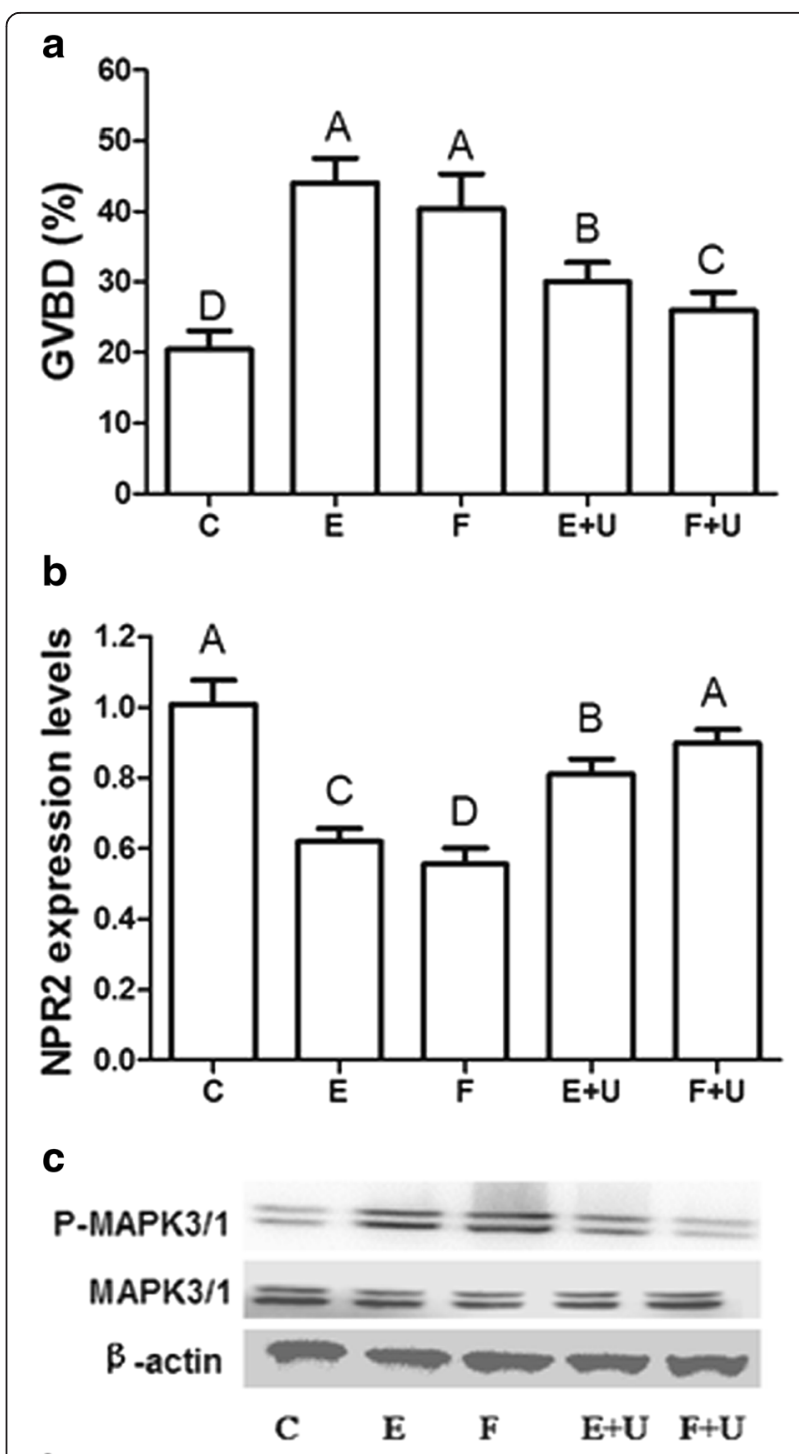

Fig. 4 The effects of U0126 on FSH- and EGF-induced oocyte meiotic resumption and NPR2 mRNA expression in COCs at $4 \mathrm{~h}$. a The GVBD rates after stimulation with FSH, EGF, FSH plus U0126 or EGF plus U0126 in COCs. $\mathbf{b}$ The mRNA expression of NPR2 after stimulation with FSH, EGF, FSH plus U0126 or EGF plus U0126 in COCs. c The phosphorylation of MAPK3/1 after stimulation with FSH, EGF, FSH plus U0126 or EGF plus U0126 in COCs. The results are presented as the mean \pm SEM and are representative of three independent experiments. C: Control; E: EGF; U: U0126; F: FSH. Different letters represent significant differences $(P<0.05)$ 
(EREG), at $2 \mathrm{~h}$ (Fig. 2). The expression of AREG, BTC and EREG transcripts increased within $2 \mathrm{~h}$ of FSH stimulation. AREG and EREG reached peak levels by $2 \mathrm{~h}$, but BTC did not. The expression of all three transcripts decreased by $8 \mathrm{~h}$. In the control groups without FSH treatment, low levels of active forms of MAPK3/1 were detected in COCs. In the FSH-induced group, MAPK3/1 activation was clearly detected in COCs at 2-8 h, but did not at $16 \mathrm{~h}$, and the greatest activation was observed at $4 \mathrm{~h}$ (Fig. $2 \mathrm{~d}$ ).

\section{EGF induces oocyte meiotic resumption, NPR2 mRNA decrease and MAPK3/1 activation}

To investigate the requirement for EGFR activity in EGFinduced GVBD, the EGFR inhibitor AG1478 was added to the medium along with $100 \mathrm{ng} / \mathrm{ml}$ EGF cultured for $4 \mathrm{~h}$. The results showed that $10 \mu \mathrm{M}$ EGFR inhibitor AG1478 prevented the oocyte meiotic resumption induced by 100 ng/ml EGF (Fig. 3a). At the same time, AG1478 partly reversed the EGF-induced decrease of NPR2 mRNA levels in COCs (Fig. 3b) and blocked the activity of MAPK3/1 in the presence of EGF (Fig. 3c).

U0126 inhibits FSH and EGF-induced oocyte meiotic resumption, NPR2 mRNA decrease and MAPK3/1 activation Whether MAPK3/1 is involved in the FSH-induced decrease in NPR2 mRNA and the mechanism by which this is regulated has never been studied. When mouse COCs were cultured and treated with EGF or FSH for $4 \mathrm{~h}, \mathrm{MAPK} 3 / 1$ was activated and GVBD occurred (Fig. 4). In addition, $5 \mu \mathrm{M}$ U0126 clearly inhibited the EGF- or FSH-stimulated oocyte meiotic resumption and MAPK3/1 activation (Fig. $4 \mathrm{a}$ and c). Furthermore, U0126 partly inhibited the EGF- and FSH-induced decrease in NPR2 (Fig. 4b).

EGFR is involved in FSH-induced oocyte meiotic resumption, NPR2 mRNA decrease and MAPK3/1 activation

Because both FSH and EGF stimulated oocyte meiotic resumption, a decrease in NPR2 levels and MAPK3/1 activation, we designed the following experiment to determine whether the induction of FSH on oocyte meiotic resumption, NPR2 mRNA decrease and MAPK3/1 phosphorylation is mediated by EGFR. FSH was added to the medium containing $10 \mu \mathrm{M}$ AG1478, and the FSHinduced oocyte meiotic resumption was decreased by the presence of AG1478 after culture for $4 \mathrm{~h}$ (Fig. 5a). In agreement with its effect on FSH-induced oocyte meiotic resumption, AG1478 also inhibited the FSH-induced MAPK3/1 activation (Fig. 5c). In addition, the FSHinduced decrease in NPR2 was partly inhibited by AG1478 (Fig. 5b).
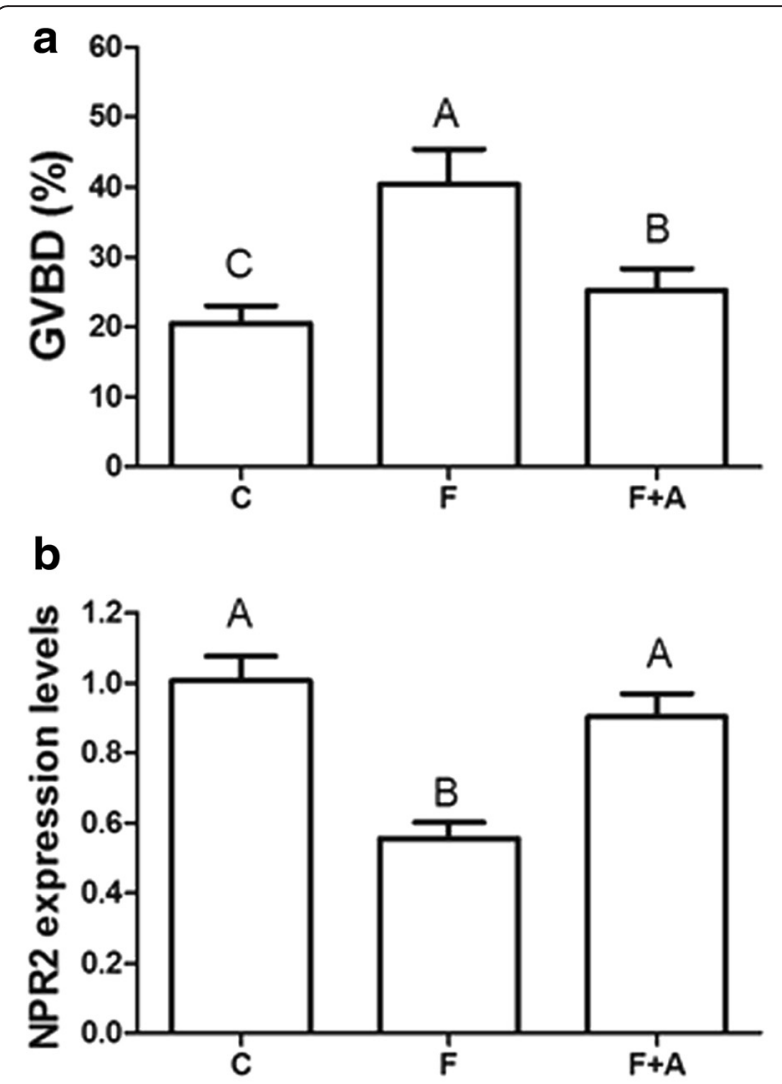

C

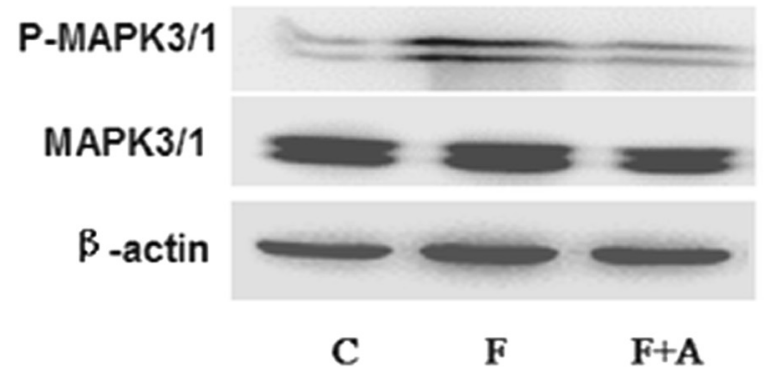

Fig. 5 The effects of AG1478 on FSH-induced oocyte meiotic resumption, NPR2 mRNA expression and MAPK3/1 activation in COCs after culture for $4 \mathrm{~h}$. a The GVBD rates after stimulation with FSH or FSH plus AG1478 in COCs. b The mRNA expression of NPR2 after stimulation with FSH or FSH plus AG1478 in COCs. c The phosphorylation of MAPK3/1 after stimulation with FSH or FSH plus AG1478 in COCs. The results are presented as the mean \pm SEM and are representative of three independent experiments. C: Control; E: EGF; A: AG1478; F: FSH. Different letters represent significant differences $(P<0.05)$

\section{Discussion}

A large number of studies have addressed the mechanism of FSH-induced oocyte maturation; however, the mechanism of oocyte maturation remains unclear. Recent studies suggested that CNP/NPR2 signaling acting as an oocyte maturation inhibitor (OMI) existed in the follicle fluid and maintained meiotic arrest [2]. 
Therefore, we first detected the pattern of NPR2 expression in COCs cultured in vitro after stimulation with FSH. The data from our study showed that NPR2 mRNA was significantly decreased during in vitro culture with FSH. Moreover, the downregulation of NPR2 mRNA in the COCs occurred between $4 \mathrm{~h}$ and $8 \mathrm{~h}$ of culture compared with the control group, and approximately $50 \%$ of oocyte germinal vesicle breakdown occurred during this period. These results further support the possible role of this gene in the regulation of oocyte meiotic resumption. Our study reported that FSH decreased the expression of NPR2 in the cultured COCs of rodent species, which was in agreement with a recent study showing that the expression of NPR2 significantly decreased in $\mathrm{FSH}$-stimulated porcine COCs cultured in vitro [26]. However, in vivo studies found that FSH induced CNP and NPR2 expression [34-36] in mouse and rat follicles. The reasons for the different in vitro and in vivo results may be because FSH stimulates follicle development in vivo [37], and bigger follicles contain higher expression levels of NPR2 [2,38].

Previous studies have indicated that the gonadotropinresponsive ovarian paracrine pathway modulates gene expression. This pathway involves LH-dependent intraovarian expression of EGF-like factors that are processed and released from the cell surface to activate EGFR in a paracrine fashion, further leading to the activation of the MAPK3/1 cascade, which regulates various cellular processes through activation of additional kinases or transcription factors to modulate gene expression $[39,40]$. In addition, there are also reports that EGFR [27] and MAPK3/1 $[41,42]$ are involved in oocyte meiotic resumption. So we tested the involvement of MAPK3/1 and EGFR in FSH-induced oocyte meiotic resumption. The results showed that FSH stimulated the expression of EGFlike factors and the phosphorylation of MAPK $3 / 1$ in COCs. Our result is consistent with previous reports that FSH stimulated the expression of EGF-like factors [31, 32] and activated MAPK3/1 [33]. Further study revealed that EGF induced oocyte meiotic resumption, NPR2 mRNA decrease and MAPK3/1 activation. Additionally, EGFmediated NPR2 mRNA decrease and meiotic resumption could be reversed with the EGFR inhibitor AG1478. This is similar to the results of a previous study that showed that the activation of EGFR by EGF suppressed NPR2 mRNA levels and meiotic resumption in mouse COCs [27]. FSH $[39,40]$ and EGFR [43] signaling-activated MAPK3/1 were associated with oocyte meiotic resumption $[41,42]$ and NPR2 mRNA decrease [27, 44]. In our study, we also found that blocking of MAPK3/1 activity by U0126 partly inhibited EGF- and FSH-induced GVBD and NPR2 mRNA decrease. Our results were similar to a previous report that the inhibition of MAPK3/1 activity by U0126 partly inhibited EGF-induced meiotic resumption [27].

\section{Conclusions}

We provide the first report that NPR2 is involved in FSH-mediated mouse oocyte meiotic resumption and that this process depends on the EGFR and MAPK3/1 signaling pathways. These results offer promising insights for identifying new components of the signaling pathways that may be involved in FSH-stimulated oocyte meiotic resumption.

\begin{abstract}
Abbreviations
AREG: amphiregulin; BTC: betacellulin; CAMP: cyclic adenosine monophosphate; CDK1: cyclin dependent kinase 1; CGMP: cyclic guanosine monophosphate; CNP: C type natriuretic peptide; COCs: cumulus oocyte complexes; EGF: epidermal growth factor; EREG: epiregulin; FSH: follicle stimulating hormone; GVBD: germinal vesicle breakdown; LH: luteinizing hormone; MAPK: mitogen activated protein kinase; MI: metaphase I; MII: metaphase II; MPF: maturation promoting factor; NPR2: natriuretic peptide receptor 2; OMl: oocyte maturation inhibitor;

PDE3A: phosphodiesterase $3 \mathrm{~A}$.
\end{abstract}

\section{Competing interests}

The authors declare that they have no competing interests.

\section{Authors' contributions}

$\mathrm{BH}, \mathrm{XZ}$ and $\mathrm{QW}$ designed the study and prepared the manuscript. LY, WL and QX performed the collection and culture of COCs. LY performed the quantitative real-time PCR and data analysis. XZ assisted in the data analysis and helped prepare the manuscript. All authors read and approved the final manuscript.

\section{Acknowledgements}

This study was supported by the Chinese Universities Scientific Fund (Program No. QN2012016) and the Undergraduate Training Programs for Innovation and Entrepreneurship of Northwest A\&F University.

Received: 30 November 2015 Accepted: 9 February 2016

Published online: 16 February 2016

\section{References}

1. Kanatsu-Shinohara M, Schultz RM, Kopf GS. Acquisition of meiotic competence in mouse oocytes: absolute amounts of p34(cdc2), cyclin B1, cdc25C, and wee1 in meiotically incompetent and competent oocytes. Biol Reprod. 2000;63:1610-6.

2. Zhang M, Su Y-Q, Sugiura K, Xia G, Eppig JJ. Granulosa cell ligand NPPC and its receptor NPR2 maintain meiotic arrest in mouse oocytes. Science. 2010; 330:366-9.

3. Shuhaibar LC, Egbert JR, Norris RP, Lampe PD, Nikolaev VO, Thunemann M, et al. Intercellular signaling via cyclic GMP diffusion through gap junctions restarts meiosis in mouse ovarian follicles. P Natl Acad Sci USA. 2015;112: 5527-32.

4. Tripathi A, Kumar KV, Chaube SK. Meiotic cell cycle arrest in mammalian oocytes. J Cell Physiol. 2010;223:592-600.

5. Zhang MJ, Hong OY, Xia GL. The signal pathway of gonadotrophinsinduced mammalian oocyte meiotic resumption. Mol Hum Reprod. 2009;15: 399-409.

6. Gonzalez-Bulnes A, Garcia-Garcia RM, Souza CJH, Santiago-Moreno J, LopezSebastian A, Cocero MJ, et al. Patterns of follicular growth in superovulated sheep and influence on endocrine and ovarian response. Reprod Domest Anim. 2002;37:357-61.

7. Grondahl C, Breinholt J, Wahl P, Murray A, Hansen TH, Faerge I, et al. Physiology of meiosis-activating sterol: endogenous formation and mode of action. Hum Reprod. 2003;18:122-9.

8. Trounson A, Anderiesz C, Jones G. Maturation of human oocytes in vitro and their developmental competence. Reproduction. 2001;121:51-75.

9. Jurema MW, Nogueira D. In vitro maturation of human oocytes for assisted reproduction. Fertil Steril. 2006;86:1277-91.

10. Sirard M-A. Follicle environment and quality of in vitro matured oocytes. J Assist Reprod Gen. 2011;28:483-8. 
11. Rossi G, Macchiarelli G, Palmerini MG, Canipari R, Cecconi S. Meiotic spindle configuration is differentially influenced by FSH and epiderma growth factor during in vitro maturation of mouse oocytes. Hum Reprod. 2006:21:1765-70.

12. Junk SM, Dharmarajan A, Yovich JL. FSH priming improves oocyte maturation, but priming with FSH or hCG has no effect on subsequent embryonic development in an in vitro maturation program. Theriogenology. 2003;59:1741-9.

13. Li J, Mao G, Xia G. FSH modulates PKAI and GPR3 activities in mouse oocyte of COC in a gap junctional communication (GJC)-dependent manner to initiate meiotic resumption. PLoS One. 2012;7, e37835.

14. Singh B, Barbe GJ, Armstrong DT. Factors influencing resumption of meiotic maturation and cumulus expansion of porcine oocyte-cumulus cell complexes in vitro. Mol Reprod Dev. 1993;36:113-9.

15. Younis A, Brackett B, Fayrer-Hosken R. Influence of serum and hormones on bovine oocyte maturation and fertilization in vitro. Gamete Research. 1989;23:189-201.

16. Tremoleda JL, Tharasanit T, Van Tol HTA, Stout TAE, Colenbrander B, Bevers MM. Effects of follicular cells and FSH on the resumption of meiosis in equine oocytes matured in vitro. Reproduction. 2003;125:565-77.

17. Bolamba D, Russ KD, Harper SA, Sandler JL, Durrant BS. Effects of epidermal growth factor and hormones on granulosa expansion and nuclear maturation of dog oocytes in vitro. Theriogenology. 2006;65:1037-47.

18. Lindner HR, Tsafriri A, Lieberman ME, Zor U, Koch Y, Bauminger S, et al. Gonadotropin action on cultured Graafian follicles: induction of maturation division of the mammalian oocyte and differentiation of the luteal cell. Recent Prog Horm Res. 1974;30:79-138.

19. Eppig JJ. The participation of cyclic adenosine monophosphate (CAMP) in the regulation of meiotic maturation of oocytes in the laboratory mouse. $J$ Reprod Fertil. 1989;38 Suppl 1:3-8.

20. Sun Q Y, Miao Y L, Schatten H. Towards a new understanding on the regulation of mammalian oocyte meiosis resumption. Cell Cycle. 2009;8: 2741-7

21. Liang CG, Huo LJ, Zhong ZS, Chen DY, Schatten H, Sun QY. Cyclic adenosine 3', 5'-monophosphate-dependent activation of mitogenactivated protein kinase in cumulus cells is essential for germinal vesicle breakdown of porcine cumulus-enclosed oocytes. Endocrinology. 2005;146:4437-44.

22. Meinecke B, Krischek C. MAPKJERK kinase (MEK) signalling is required for resumption of meiosis in cultured cumulus-enclosed pig oocytes. Zygote. 2003;11:7-16.

23. Richani D, Ritter L, Thompson J, Gilchrist R. Mode of oocyte maturation affects EGF-like peptide function and oocyte competence. Mol Hum Reprod. 2013;19:500-9.

24. Caixeta ES, Machado MF, Ripamonte P, Price C, Buratini J. Effects of FSH on the expression of receptors for oocyte-secreted factors and members of the EGF-like family during in vitro maturation in cattle. Reprod Fertil Dev. 2013;25:890-9.

25. Yamashita $Y$, ShiMADA M. The release of EGF domain from EGF-like factors by a specific cleavage enzyme activates the EGFR-MAPK3/1 pathway in both granulosa cells and cumulus cells during the ovulation process. Reprod Develop. 2012;58:510-4.

26. Blaha M, Nemcova L, Prochazka R. Cyclic guanosine monophosphate does not inhibit gonadotropin-induced activation of mitogen-activated protein kinase 3/1 in pig cumulus-oocyte complexes. Reprod Biol Endocrin. 2015;13:1.

27. Wang Y, Kong N, Li N, Hao X, Wei K, Xiang X, et al. Epidermal growth factor receptor signaling-dependent calcium elevation in cumulus cells is required for NPR2 inhibition and meiotic resumption in mouse oocytes. Endocrinology. 2013;154:3401-9.

28. De S, Kline D. Evidence for the requirement of 14-3-3eta (YWHAH) in meiotic spindle assembly during mouse oocyte maturation. BMC Dev Biol. 2013;13:10

29. Fan $\mathrm{H}-\mathrm{Y}$, Huo L-J, Chen D-Y, Schatten H, Sun Q-Y. Protein kinase C and mitogen-activated protein kinase cascade in mouse cumulus cells: cross talk and effect on meiotic resumption of oocyte. Biol Reprod. 2004;70:1178-87.

30. Sugiura K, Su YQ, Eppig JJ. Targeted suppression of Has 2 mRNA in mouse cumulus cell-oocyte complexes by adenovirus-mediated short-hairpin RNA expression. Mol Reprod Dev. 2009;76:537-47.

31. Chen X, Zhou B, Yan J, Xu B, Tai P, Li J, et al. Epidermal growth factor receptor activation by protein kinase $\mathrm{C}$ is necessary for $\mathrm{FSH}$-induced meiotic resumption in porcine cumulus-oocyte complexes. J Endocrinol. 2008;197:409-19.
32. Prochazka R, Blaha M, Nemcova L. Signaling pathways regulating FSH-and amphiregulin-induced meiotic resumption and cumulus cell expansion in the pig. Reproduction. 2012;144:535-46.

33. Su Y-Q, Wigglesworth K, Pendola FL, O'Brien MJ, Eppig JJ. Mitogen-activated protein kinase activity in cumulus cells is essential for gonadotropininduced oocyte meiotic resumption and cumulus expansion in the mouse. Endocrinology. 2002;143:2221-32.

34. Kawamura K, Cheng Y, Kawamura N, Takae S, Okada A, Kawagoe Y, et al. Pre-ovulatory LH/hCG surge decreases C-type natriuretic peptide secretion by ovarian granulosa cells to promote meiotic resumption of pre-ovulatory oocytes. Hum Reprod. 2011:26:3094-101.

35. Lee K-B, Zhang M, Sugiura K, Wigglesworth K, Uliasz T, Jaffe LA, et al. Hormonal coordination of natriuretic peptide type $C$ and natriuretic peptide receptor 3 expression in mouse granulosa cells. Biol Reprod. 2013;88:42.

36. Zhang M, Su Y-Q, Sugiura K, Wigglesworth K, Xia G, Eppig JJ. Estradiol promotes and maintains cumulus cell expression of natriuretic peptide receptor 2 (NPR2) and meiotic arrest in mouse oocytes in vitro. Endocrinology. 2011;152:4377-85.

37. Sato Y, Cheng Y, Kawamura K, Takae S, Hsueh AJ. C-type natriuretic peptide stimulates ovarian follicle development. Mol Endocrinol. 2012;26:1158-66.

38. Zhang J, Wei Q, Cai J, Zhao X, Ma B. Effect of C-type natriuretic peptide on maturation and developmental competence of goat oocytes matured in vitro. PLoS One. 2015;10

39. Yarden Y, Sliwkowski MX. Untangling the ErbB signalling network. Nat Rev Mol Cell Bio. 2001;2:127-37.

40. Holbro T, Hynes NE. ErbB receptors: directing key signaling networks throughout life. Annu Rev Pharmacol. 2004;44:195-217.

41. Dedieu T, Gall L, Crozet N, Sevellec C, Ruffini S. Mitogen-activated protein kinase activity during goat oocyte maturation and the acquisition of meiotic competence. Mol Reprod Dev. 1996;45:351-8.

42. Schmitt A, Nebreda AR. Signalling pathways in oocyte meiotic maturation. J Cell Sci. 2002;115:2457-9.

43. Su Y-Q, Denegre JM, Wigglesworth K, Pendola FL, O'Brien MJ, Eppig JJ. Oocyte-dependent activation of mitogen-activated protein kinase (ERK1/2) in cumulus cells is required for the maturation of the mouse oocytecumulus cell complex. Dev Biol. 2003;263:126-38.

44. Tsuji T, Kiyosu C, Akiyama K, Kunieda T. CNP/NPR2 signaling maintains oocyte meiotic arrest in early antral follicles and is suppressed by EGFR-mediated signaling in preovulatory follicles. Mol Reprod Dev. 2012;79:795-802.

\section{Submit your next manuscript to BioMed Central and we will help you at every step:}

- We accept pre-submission inquiries

- Our selector tool helps you to find the most relevant journal

- We provide round the clock customer support

- Convenient online submission

- Thorough peer review

- Inclusion in PubMed and all major indexing services

- Maximum visibility for your research

Submit your manuscript at www.biomedcentral.com/submit

) Biomed Central 